\title{
AKTIVITAS ANTIOKSIDAN EKSTRAK DAN FRAKSI DARI RIMPANG JAHE BALIKPAPAN (ETLINGERA BALIKPAPANENSIS)
}

\author{
Atria Kent*, Agung Rahmadani, Rolan Rusli \\ Program Studi S1 Fakultas Farmasi, Universitas Mulawarman \\ Kampus Unmul Gunung Kelua Kota Samarinda 75119 \\ *email : atriakent15@gmail.com
}

\begin{abstract}
ABSTRAK
Jahe Balikpapan (Etlingera balikpapanensis A.D. Poulsen) merupakan tumbuhan yang termasuk dalam keluarga zingiberaceae (jahe-jahean). Tumbuhan-tumbuhan dari keluarga jahe-jahean telah diketahui memiliki bnayak manfaat. Salah satu dari manfaatnya adalah memiliki aktivitas antioksidan yang baik. Pada penelitian ini dilakukan ekstraksi dan fraksinasi sehingga diperoleh ekstrak metanol, fraksi n-heksana, fraksi etil asetat dan fraksi metanol (tidak larut). Telah dilakukan penelitian mengenai aktivitas antioksidan dari jahe balikpapan dengan metode DPPH. Hasil yang diperoleh untuk aktivitas antioksidan (IC ${ }_{50}$ ) pada ekstrak metanol, fraksi n-heksana, fraksi etil asetat, dan fraksi metanol (tidak larut) masing-masing adalah 131,412 ppm, 190,933 ppm, 58,392 ppm, dan 91,8 ppm. Hasil tersebut dibandingakan dengan Aktivitas antioksidan $\left(\mathrm{IC}_{50}\right)$ dari vitamin $\mathrm{C}$ yaitu sebasar 6,96 ppm.
\end{abstract}

Kata Kunci : Antioksidan, Jahe balikpapan, DPPH, $\mathrm{IC}_{50}$

\section{ABSTRACT}

Jahe balikpapan (Etlingera balikpapanensis A.D. Poulsen) are plant from family zingiberaceae. The plants from Family zigiberaceae are known having so many benefits. One of the benefits is have good antioxidant activity. This research was conducted by extraction and fractination that produce methanol extract, $n$-hexane fraction, ethyl acetate fraction, and methanol fraction (not dissolved). This research was tested the antioxidant activity from jahe balikpapan's rhizome used DPPH method. The obtained results showed the activity antioxidant $\left(I C_{50}\right)$ from methanol extract, $n$-hexane fraction, ethyl acetate fraction, and methanol fraction (not dissolved) were 131,412 ppm, 190,933 ppm, 58,392 ppm, dan 91,8 ppm. That results compared to the antioxidant activity of vitamin $c$ is equal to $6,96 \mathrm{ppm}$.

Keywords : Antioxidant, Jahe balikpapan, DPPH, $I C_{50}$

\section{PENDAHULUAN}

Kalimantan Timur merupakan salah satu provinsi di Indonesia yang memiliki berbagai jenis tumbuhan, salah satunya adalah tumbuhan jahe balikpapan yang merupakan keluarga jahe-jahean (Zingiberaceae). Zingiberaceae adalah keluarga tumbuhan yang telah digunakan dalam pengobatan tradisional sejak bertahun-tahun. sekitar 40 spesies dari genus Etlingera dan 29 spesies dari genus Zingiber dapat ditemukan di pulau Kalimantan. Salah 
satunya adalah Jahe Balikpapan (Etlingera balikpapanesis A.D Poulson) yang ditemukan di kota balikpapan pada tahun 2006 oleh ahli botani yang berasal dari Denmark (Poulson, 2006).

Secara tradisional, keluarga Zingiberaceae sering digunakan sebagai bahan dalam jamu (obat tradisional indonesia). Bagian stem dari spesies Costud speciosus telah digunakan secara tradisional untuk mengobati asma dan flu. Rimpang dari Curcuma longa dan Zingiber officinale digunakan untuk mengatasi inflamasi. Kaempheria galanga telah digunakan untuk mengurangi rasa sakit pada wanita setelah melahirkan. Secara tradisional atau empiris di malaysia Etlingera belalongensi telah digunakan untuk mengobati demam dan penyakit saluran kemih (Sabli dkk., 2012).

Dalam beberapa dekade terakhir, jahe-jahean dipelajari secara ekstensif dalam pengobatan dengan teknik ilmiah dan diketahui mengandung berbagai senyawa bioaktif seperti tanin, flavonoid, glikosida, minyak atsiri, furostanol, spirostanol, saponin, fitosterol, amida, alkaloid telah diisolasi dari berbagai bagian tanaman dan dianalisis secara farmakologi. Komposisi fitokimia rimpang E. elatior telah diteliti. Ekstrak kasar etanol mengandung tanin, senyawa fenolik, flavonoid dan terpenoid (Sabli dkk., 2012).

Antioksidan adalah zat yang dapat melawan dan menghancurkan radikal bebas yang berlebihan dan untuk perbaikan oksidatif. Saat ini, antioksidan sintetik yang banyak digunakan dalam industri makanan. Penggunaan antioksidan alami lebih aman daripada antioksidan sintetik. Antioksidan alami dari tanaman banyak dipelajari saat ini.

Aktivitas antioksidan tertinggi bagian yang berbeda dari jahe ditemukan pada rimpang. Senyawa hasil dari rimpang Zingiber cassumunins menunjukkan aktivitas antioksidan yang cukup tinggi (Masuda \& Jitoe, 1994). Chen \& dou (2008) meneliti aktivitas antioksidan dari 26 spesies Zingiberaceae di semenanjung Malaysia dan hasilnya menunjukkan bahwa spesies Etlingera memiliki sifat antioksidan yang secara signifikan lebih tinggi dibandingkan dengan genus lainnya. Antioksidan menjadi senyawa yang sangat dibutuhkan dan bermanfaat dalam kehidupan sehingga perlu dikembangkan sumbernya yang berupa sumber alami maupun sintetis. Hal tersebut menjadi alasan peneliti melakukan penelitian aktivitas antioksidan.

\section{METODE PENELITIAN}

\section{Bahan Penelitian}

Simplisia jahe balikpapan (E. balikpapanensis), pelarut metanol, 1.1-Diphenyl-2Picrylhydrazyl (DPPH), N-heksana, etil asetat. 


\section{Penyiapan sampel}

Sampel yang berupa rimpang jahe balikpapan segar dikupas kulitnya, disortasi basah kemudian dicuci dengan air bersih lalu dipotong kecil-kecil. Setelah itu dikeringkan dengan oven pada suhu $60^{\circ} \mathrm{C}$ sampai benar-benar kering kemudian disortasi kering.

\section{Ektraksi sampel}

Ekstraksi dilakukan dengan cara sebanyak 500 gram sampel rimpang jahe balikpapan segar dimaserasi dengan metanol selama 3 hari, lalu disaring. Proses maserasi dan penyaringan dilakukan dengan beberapa kali pengulangan sampai diperoleh filtrat yang bening. Filtrat diuapkan dengan rotary evaporator pada suhu $40^{\circ} \mathrm{C}$ sampai mengental kemudian dikeringkan diatas penangas untuk menghasilkan ekstrak yang benar-benar kering, lalu ditimbang dan dihitung jumlah rendemen yang dihasilkan lalu Ekstrak yang dihasilkan disimpan pada suhu ruang untuk digunakan pada analisis berikutnya. Perhitungan rendemen ekstrak adalah sebagai berikut :

$$
\text { Rendemen }=\frac{\text { Berat Hasil Ekstraksi }}{\text { Berat Sampel Segar }} \times 100 \%
$$

Jumlah rendemen yang dihasilkan dapat dilihat pada Tabel 1.

Tabel 1. Jumlah Rendemen

\begin{tabular}{llll}
\hline No. & Bahan Uji & Berat (gram) & Rendemen (\%) \\
\hline 1. & Ekstrak & 96,8 & $8,73 \%$ \\
2. & Fraksi N-heksana & 6,7 & $67 \%$ \\
3. & Fraksi Etil Asetat & 3,2 & $32 \%$ \\
4. & Fraksi metanol (tidak larut) & 0,05 & $0,5 \%$ \\
\hline
\end{tabular}

\section{Fraksinasi}

Ekstrak kering jahe balikpapan ditimbang sebanyak 10 gram kemudian dilarutkan dengan $250 \mathrm{~mL}$-heksana dimasukkan ke dalam erlenmeyer bertutup lalu distrirer. Setelah itu disaring larutan dengan kertas saring. Ekstrak yang tidak larut dimasukkan kembali ke erlenmeyer bertutup kemudian ditambahkan n-heksana dan distirer kembali. Proses tersebut diulang hingga larutan bening. Setelah didapatkan fraksi tersebut diuapkan pelarutnya hingga kental dan dikeringkan. Dilanjutkan proses yang sama dengan pelarut etil asetat. Ekstrak yang tidak larut dalam n-heksana maupun etil asetat sebagai fraksi metanol tidak larut. Larutan bening sisa fraksinasi dengan etil asetat disentrifugasi hingga terbentuk endapan kemudian pelarut dibuang dan dikeringkan endapan maka didapatkan fraksi metanol tidak larut. 


\section{Pengujian Aktivitas Antioksidan}

Untuk penentuan aktivitas antioksidan ekstrak dan fraksi rimpang jahe balikpapan menggunakan metode peredaman radikal bebas DPPH. Sebanyak $2 \mathrm{mg}$ ekstrak dan fraksi rimpang jahe balikpapan dilarutkan dalam metanol. Sebanyak $2 \mathrm{~mL}$ larutan ekstrak tersebut ditambahkan dengan $3 \mathrm{~mL}$ larutan DPPH 20 ppm dan dibiarkan selama 20 menit pada temperatur ruang (terhindar dari cahaya). Pengukuran absorban dilakukan pada panjang gelombang $517 \mathrm{~nm}$. Sebagai pembanding digunakan vitamin C. Perhitungan \% inhibisi menggunakan persamaan:

$$
\text { Inhibisi }(\%)=\frac{(\text { Absorbansi blanko-Absorbansi sampel })}{\text { Absorbansi blanko }} \times 100 \%
$$

Data aktivitas antioksidan dapat dilihat pada Tabel 2.

Tabel 2. Hasil pengujian antioksidan

\begin{tabular}{|c|c|c|c|c|}
\hline Sampel & $\begin{array}{c}\text { Konsentrasi } \\
\text { Uji (ppm) }\end{array}$ & $\begin{array}{l}\% \text { Aktivitas } \\
\text { Antioksidan }\end{array}$ & IC $C_{50}$ & Keterangan \\
\hline \multirow[t]{5}{*}{ Ekstrak Metanol } & 15 & 9,885 & 131,41 & Sedang \\
\hline & 30 & 18,528 & & \\
\hline & 45 & 23,582 & & \\
\hline & 60 & 27,305 & & \\
\hline & 75 & 29,965 & & \\
\hline \multirow[t]{5}{*}{ Fraksi N-Heksana } & 15 & 2,343 & 190,93 & Lemah \\
\hline & 30 & 7,889 & & \\
\hline & 45 & 11,301 & & \\
\hline & 60 & 15,920 & & \\
\hline & 75 & 19,829 & & \\
\hline \multirow[t]{5}{*}{ Fraksi Etil Asetat } & 15 & 20,702 & 58,39 & Kuat \\
\hline & 30 & 33,765 & & \\
\hline & 45 & 44,054 & & \\
\hline & 60 & 50,154 & & \\
\hline & 75 & 56,932 & & \\
\hline \multirow[t]{5}{*}{ Fraksi Metanol (Tidak Larut) } & 15 & 0,428 & 91,8 & Kuat \\
\hline & 30 & 0,386 & & \\
\hline & 45 & 27,216 & & \\
\hline & 60 & 32,027 & & \\
\hline & 75 & 42,955 & & \\
\hline
\end{tabular}




\section{HASIL DAN PEMBAHASAN}

Diperoleh hasil rendemen ekstrak yaitu sebesar 8,73 \% dari berat simplisia 1108 gram sedangkan rendemen fraksi n-heksana, fraksi etil asetat, fraksi metanol (tidak larut) yang dihasilkan berturut-turut adalah 67\%,32 \%, dan 0,05\% dari berat ekstrak 10 gram. Aktivitas Antioksidan ekstrak dan fraksi rimpang jahe balikpapan (E. balikpapanensis) dilakukan dengan metode DPPH. Dari hasil yang diperoleh diketahui nilai IC $_{50}$ dari ekstrak metanol rimpang jahe balikpapan yaitu sebesar 131,412 ppm, sedangkan untuk fraksi n-heksana, fraksi etil asetat, dan fraksi metanol (tidak larut) berturut-turut yaitu sebesar 190,933, 58,392, dan 91,8. IC 50 merupakan bilangan yang menunjukan konsentrasi sampel (ppm) yang mampu menghambat radikal bebas sebesar $50 \%$. Semakin kecil nilai $\mathrm{IC}_{50}$ berarti semakin tinggi aktivitas antioksidan. Secara spesifik suatu senyawa dikatakan sebagai antioksidan sangat kuat jika nilai IC $_{50}$ kurang dari 50 ppm, kuat untuk IC $_{50}$ bernilai 50-100 ppm, sedang jika bernilai 100-150 ppm, dan lemah jika IC 50 bernilai 151-200 ppm (Zuhra, 2008). Potensi aktivitas antioksidan dari rimpang jahe balikpapan lebih rendah jika dibandingkan dengan nilai $\mathrm{IC}_{50}$ dari vitamin $\mathrm{C}$ yaitu sebesar 6,98 (Marliani, 2014).

\section{KESIMPULAN}

1. Rendemen ekstrak rimpang jahe balikpapan (E. balikpapanensis) yang diperoleh yaitu $8,73 \%$, sedangkan rendemen fraksi n-heksana, fraksi etil asetat, dan fraksi metanol (tidak larut) berturut-turut yaitu $67 \%, 32 \%$, dan $0,5 \%$.

2. Nilai IC 50 $_{0}$ dari ekstrak metanol yaitu 131,412 ppm, fraksi n-heksana sebesar 190,933 ppm, fraksi etil asetat sebesar 58,392 ppm, dan fraksi metanol (tidak larut) sebesar 91,8 ppm.

3. Aktivitas antioksidan eksrak dan fraksi dari rimpang jahe balikpapan ( $E$. balikpapanensis) lebih rendah dibandingkan kontrol positif vitamin C.

\section{DAFTAR PUSTAKA}

Marliani, Lia. 2014. Aktivitas Antioksidan Daun dan Buah Jamblang (Syzigum cumini L.) Skeel. Jurnal Sains, Teknologi dan Kesehatan. Vol. 4. No.1.

Zuhra, Cut Fatimah. 2008. Aktivitas Natioksidan Senyawa Flavanoid Daun Katuk ( Sauropus androgunus (L). Merr.). Jurnal Biologi Sumatera Vol. 3. No. 1.

Poulson, A. D., 2006. Ginger of sarawak. Natural History publication, Borneo, Kota Kinabalu, Sabah, Malaysia.

Poulson, A.D., 2006. Etlingera From Borneo. Natural History Publication. Borneo. 
Sabli, Farrawati. 2012. Antioxidant Properties of Selected Etlingera and Zingiber Species (Zingiberaceae) From Borneo Island. Int. J. Biol. Chem.2012.

Masuda,T. and A. Jitoe, 1994. Antioxidative and antiinflammatory compounds from tropical gingers : determination and activities of cassumunins $\mathrm{A}, \mathrm{B}$, and $\mathrm{C}$, new complex curcuminoids from zingiber cassumunar. J.Agric. Food Chem., 42 : 1850-1856.

Chen, D and Q. P. Dou. 2008. Tea Polyphenol And Their Roles In Cancer Prevention And Chemotherapy. Int.J.Mol.Sci.,9 :1196-1206 